\title{
Springtail (Hexapoda: Collembola) fauna in the burnt boreal forests of European Russia
}

\author{
R.A. Saifutdinov ${ }^{1,2}$, K.B. Gongalsky ${ }^{1}$, A.S. Zaitsev ${ }^{1,3}$ \\ ${ }^{I}$ A.N. Severtsov Institute of Ecology and Evolution, Russian Academy of Sciences, Leninsky pr., 33, \\ Moscow119071 Russia.E-mail: gongalsky@gmail.com \\ 2 Kazan Federal University, Kremlyovskaya str. 18, Kazan 420008 Russia. E-mail: \\ saifutdinov@biogeo.ru \\ ${ }^{3}$ Institute of Animal Ecology, Justus-Liebig-University, Heinrich-Buff-Ring 26, 35392 Giessen, \\ Germany.E-mail: andrey.zaytsev@biogeo.ru
}

ABSTRACT: We investigated fauna and community composition of springtails in the burnt and unburnt boreal forests of European Russia. We also analyzed ecoregional differences in the effect of fire disturbance on collembolan community faunistic similarity on an example of three different ecoregions of the boreal forest biome in the study territory. We collected and identified 6799 springtail individuals representing 14 families, 41 genera and 94 species. In the burnt plots we observed consistent shifts in the springtail community dominance structure across all studied ecoregions. The effect of fire on the faunistic similarity of springtail communities was strongly modulated by ecoregion: within-ecoregion similarity between plots was always higher than the between-region similarity. Fires resulted in the moderate decrease of the total abundance of springtails with trans-holarctic distribution in all ecoregions and additionally in increase of springtails with west-palaearctic distribution in southern ecoregion. We conclude that five years after burning it is very important to standardize fire-induced changes in the faunistic composition of springtail communities to the actual geographic location within spatially extensive biomes.

How to cite this article: Saifutdinov R.A., Gongalsky K.B., Zaitsev A.S. 2018. Springtail (Hexapoda: Collembola) fauna in the burnt boreal forests of European Russia // Invert. Zool. Vol.15. No.1. P. 115-130. doi: 10.15298/invertzool.15.1.09

KEY WORDS: soil fauna, taiga, fire disturbance, collembolans, European Russia.

\section{Фауна ногохвосток (Hexapoda: Collembola) в сгоревших бореальных лесах европейской части России}

\footnotetext{
Р.А. Сайфутдинов ${ }^{1,2}$, К.Б. Гонгальский ${ }^{1}$, А.С. Зайцев ${ }^{1,3}$

${ }^{1}$ Институт проблем экологии и эволючии им. А.Н. Севериова РАН, Ленинский пр., 33, Москва 119071 Pоссия. E-mail: gongalsky@gmail.com

${ }^{2}$ Казанский федеральный университет, ул. Кремлёвская 18, Казань 420008 Россия. E-таil: saifutdinov@biogeo.ru

${ }^{3}$ Институт экологии животных, Университет им. Юстуса-Либиха, Хайнрих-Буфф-Ринг 26, 35392 Гиссен, Германия. E-mail: andrey.zaytsev@biogeo.ru
}

РЕЗЮМЕ: Исследовали фауну и структуру сообществ ногохвосток в сгоревших и естественных бореальных лесах европейской части России. На примере трёх разных 
экорегионов анализировали влияние различий в экорегионах при воздействии лесных пожаров на фаунистическую структуру таксоценов коллембол. Всего было собрано и определено 6799 экземпляров коллембол, представляющих 14 семейств, 41 род и 94 вида. Сгоревшие участки всех исследуемых экорегионов характеризуются нарушенной структурой доминирования таксоценов коллембол. Таксоцены коллембол в большей степени определяются региональными факторами, нежели влиянием на них лесных пожаров: фаунистическое сходство таксоценов коллембол между участками внутри экорегионов было выше сходства участков между экорегионами. Пожары привели к сокращению общей численности ногохвосток с трансголарктическим распределением во всех экорегионах и дополнительно, к увеличению численности ногохвосток с западно-палеарктическим распределением в южном экорегионе. Мы пришли к выводу, что спустя пять лет после лесного пожара важна стандартизация изменений, вызванных пожаром, в фаунистическом составе сообществ ногохвосток к фактическому географическому местоположению в пределах крупных зональных биомов.

Как цитировать эту статью: : Saifutdinov R.A., Gongalsky K.B., Zaitsev A.S. 2018. Springtail (Hexapoda: Collembola) fauna in the burnt boreal forests of European Russia // Invert. Zool. Vol.15. No.1. P. 115-130. doi: 10.15298/invertzool.15.1.09

КЛЮЧЕВЫЕ СЛОВА: почвенная фауна, тайга, лесной пожар, коллемболы, Европейская часть России.

\section{Introduction}

Springtails are small invertebrates that inhabit almost any soil type around the globe (Hopkin, 1997; Rusek, 1998). They form a considerable part of soil microarthropod biodiversity and contribute to soil decomposition and mineralization processes, particularly in the boreal forests (Petersen, Luxton, 1982; Seastedt, 1984; Huhta et al., 1998). At the same time, springtail community composition may vary considerably across this biome depending on climate and dominating species in tree stands (Juceviča, Melecis, 2002; Kuznetsova, 2002). Despite numerous studies published with this respect (see e.g. Kuznetsova, Potapov, 1997; Kuznetsova, Krest'yaninova, 1998; Chernova, Kuznetsova, 2000; Taskaeva, 2009, 2011), not much is still known on the impact of different disturbances on fauna and taxonomic composition of collembolans (Malmström, 2012). Given that wildfires are one of the most important disturbances in the boreal forests, they remain unstudied in terms of soil faunal recovery with respect to macrogeographic gradients present- ed within NW Russia's boreal forests (see e.g. Zaitsev et al., 2016 for review).

We tried to address this knowledge gap by studying the effect of forest fires which are frequent in the boreal forests of European Russia. We aimed at understanding, how forest fires alter faunistic composition and the diversity of soil microarthropod communities at the local scale and how consistent are the revealed effects at the ecoregion scale.

\section{Material and methods}

\section{Study sites}

The study was conducted along a $1500 \mathrm{~km}$ long latitudinal gradient in the boreal forests of European Russia (Fig. 1). We selected three ecoregions in the European Russia: Kola-Karelian, Pribaltiiskiy-Vetluzhskiy and SmolenskPriuralskiy ecoregions (Ogureeva et al., 2015). Studied ecoregions corresponds to the different type of forest within boreal forest biome as follows: Kola-Karelian — northern taiga, Pribaltiiskiy-Vetluzhskiy — middle taiga and Smolensk-Priuralskiy — southern taiga. 


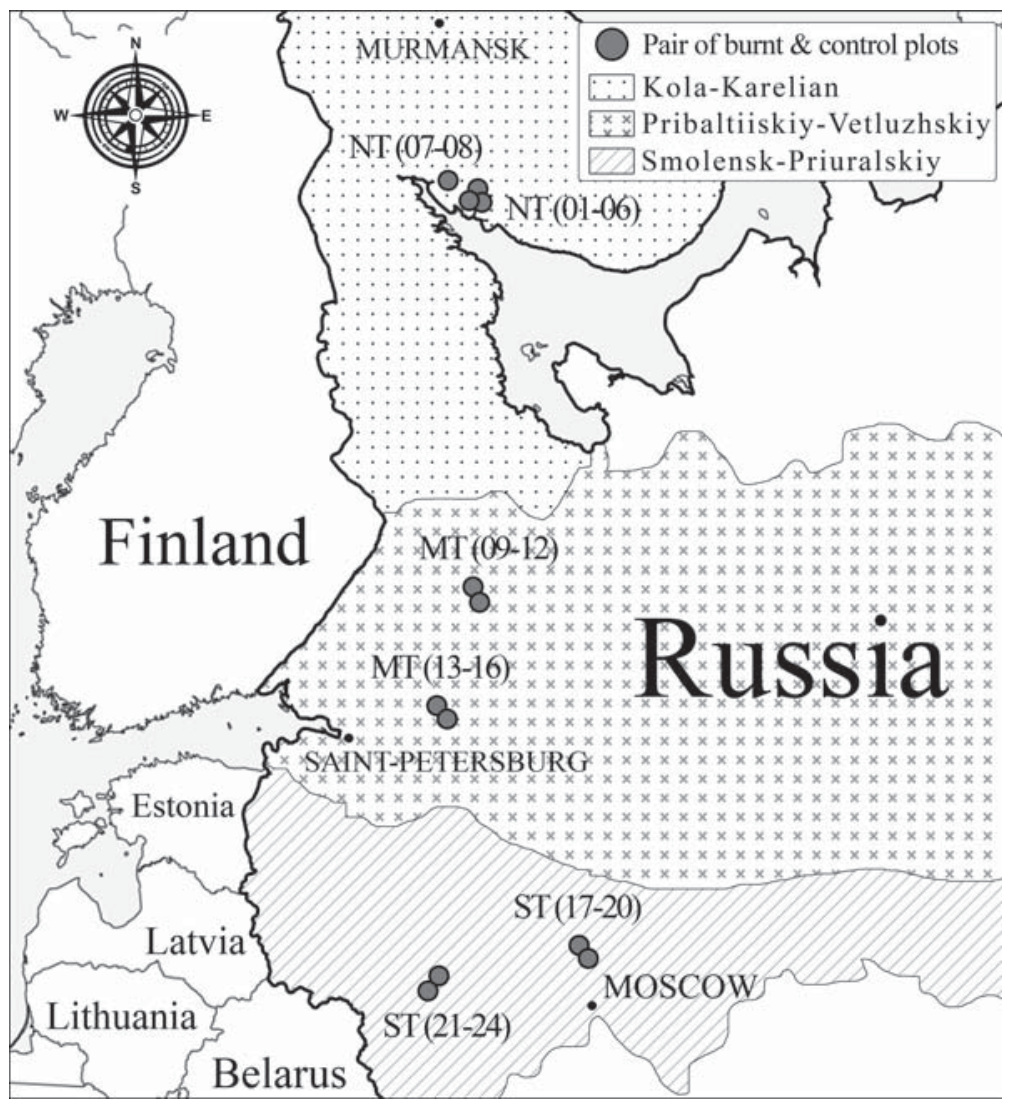

Fig. 1. Schematic map of the studied ecoregions (Kola-Karelian, Pribaltiiskiy-Vetluzhskiy and SmolenskPriuralskiy) within the boreal biome in NW Russia. Gray dots indicate pairs of forest plots (burnt and control) sampled within each ecoregion. Numbers in parentheses refer to respective plots as shown in Table 1.

Рис. 1. Схематическая карта исследуемых экорегионов (Кольско-Карельский, Прибалтийско-Ветлужский, Смоленск-Приуральский) биома бореальных лесов северо-западной части России. Серые точки обозначают пары лесных участков (сгоревших и контрольных), отобранных в каждом экорегионе. Номера чисел в скобках обозначают пары исследуемых участков, и соответствуют участкам в таблице 1.

Plots of Kola-Karelian ecoregion are located in the Murmansk Region, Kola Peninsula (Fig. 1) and are represented by pine (Pinus sylvestris L., 1753) or pine-spruce (P. sylvestris, Picea abies H. Karst., 1881) forest stands (Table 1). The ground vegetation is formed predominantly by red bilberry (Vaccinium vitisidaea L., 1753) and blueberry (V. myrtilis L., 1753). Soil type is Albic Podzols according to World Reference Base for Soil Recourses classification (WRB, 2015).

Pribaltiiskiy-Vetluzhskiy ecoregion plots are located in the Republic of Karelia and the Leningrad Region. They are represented by pine for- ests (P. sylvestris) with blueberry ( $V$. myrtilis) and red bilberry ( $V$. vitis-idaea) in the undergrowth. Soil types are Lithic Leptosols or Albic Podzols (WRB, 2015).

Smolensk-Priuralskiy ecoregion forests are located in the Moscow and Tver Regions and are formed by spruce-birch (P. abies, Betula pendula Roth, 1788), pine-birch (B. pendula, $P$. sylvestris) or spruce-pine-birch stands (B. pendula, P. abies, $P$. sylvestris). Ground vegetation is dominated mainly by red bilberry ( $V$. vitisidaea) and blueberry (V.myrtilis). Soil type is Umbric Albeluvisol (WRB, 2015). 
Table 1. Brief description of investigated forest plots. Even plot numbers refer to the burnt and odd numbers to the control forests within the respective plot pair.

Таблица 1. Краткая характеристика исследуемых лесных участков. Чётные номера обозначают сгоревшие и нечётные - контрольные участки в пределах соответствующей пары.

\begin{tabular}{|c|c|c|c|c|}
\hline Plot pair No & Ecoregion & Locality & $\begin{array}{l}\text { Geographic } \\
\text { coordinates }\end{array}$ & $\begin{array}{l}\text { Dominating tree } \\
\text { species }\end{array}$ \\
\hline NT-01,02 & Kola-Karelian & Umba & $\begin{array}{l}66.82928^{\circ} \mathrm{N} \\
34.03890^{\circ} \mathrm{E}\end{array}$ & Pinus sylvestris \\
\hline NT-03,04 & Kola-Karelian & Umba & $\begin{array}{l}66.79567^{\circ} \mathrm{N} \\
34.18753^{\circ} \mathrm{E}\end{array}$ & $\begin{array}{l}\text { P. sylvestris, Picea } \\
\text { abies }\end{array}$ \\
\hline NT-05,06 & Kola-Karelian & Umba & $\begin{array}{l}66.78124^{\circ} \mathrm{N} \\
34.19601^{\circ} \mathrm{E}\end{array}$ & P. sylvestris \\
\hline NT-07,08 & Kola-Karelian & Kolvitsa & $\begin{array}{l}67.07881^{\circ} \mathrm{N} \\
33.17981^{\circ} \mathrm{E}\end{array}$ & P. sylvestris \\
\hline MT-09,10 & $\begin{array}{l}\text { Pribaltiiskiy- } \\
\text { Vetluzhskiy }\end{array}$ & $\begin{array}{l}\text { Petro- } \\
\text { zavodsk }\end{array}$ & $\begin{array}{l}61.99292^{\circ} \mathrm{N} \\
34.17444^{\circ} \mathrm{E}\end{array}$ & $\begin{array}{l}\text { P. sylvestris, Betula } \\
\text { pendula }\end{array}$ \\
\hline MT-11,12 & $\begin{array}{l}\text { Pribaltiiskiy- } \\
\text { Vetluzhskiy }\end{array}$ & $\begin{array}{l}\text { Petro- } \\
\text { zavodsk }\end{array}$ & $\begin{array}{l}61.85056^{\circ} \mathrm{N} \\
34.41325^{\circ} \mathrm{E}\end{array}$ & $\begin{array}{l}\text { P. sylvestris, Sorbus } \\
\text { aucuparia }\end{array}$ \\
\hline MT-13,14 & $\begin{array}{l}\text { Pribaltiiskiy- } \\
\text { Vetluzhskiy }\end{array}$ & Pasha & $\begin{array}{l}60.33975^{\circ} \mathrm{N} \\
33.13269^{\circ} \mathrm{E}\end{array}$ & P. sylvestris \\
\hline MT-15,16 & $\begin{array}{l}\text { Pribaltiiskiy- } \\
\text { Vetluzhskiy }\end{array}$ & Pasha & $\begin{array}{l}60.32878^{\circ} \mathrm{N} \\
33.14875^{\circ} \mathrm{E}\end{array}$ & P. sylvestris \\
\hline ST-17,18 & $\begin{array}{l}\text { Smolensk- } \\
\text { Priuralskiy }\end{array}$ & Taldom & $\begin{array}{l}56.647912^{\circ} \mathrm{N} \\
37.443685^{\circ} \mathrm{E}\end{array}$ & P. abies, B. pendula \\
\hline ST-19,20 & $\begin{array}{l}\text { Smolensk- } \\
\text { Priuralskiy }\end{array}$ & Taldom & $\begin{array}{l}56.521919^{\circ} \mathrm{N} \\
37.62822^{\circ} \mathrm{E}\end{array}$ & $\begin{array}{l}\text { P. abies, } P \text {. sylvestris, } \\
\text { B. pendula }\end{array}$ \\
\hline ST-21,22 & $\begin{array}{l}\text { Smolensk- } \\
\text { Priuralskiy }\end{array}$ & Nelidovo & $\begin{array}{l}56.155257^{\circ} \mathrm{N} \\
32.817537^{\circ} \mathrm{E}\end{array}$ & $\begin{array}{l}\text { P. abies, } S \text {. } \\
\text { aucuparia }\end{array}$ \\
\hline ST-23,24 & $\begin{array}{l}\text { Smolensk- } \\
\text { Priuralskiy }\end{array}$ & Nelidovo & $\begin{array}{l}56.140112 \mathrm{~N} \\
32.718251 \mathrm{E}\end{array}$ & P. abies, B. pendula \\
\hline
\end{tabular}

In each ecoregion, we selected four forest plots burnt in 2010 and four respective controls. In total we examined 12 pairs of plots (burntcontrol). Some further details on the investigated plots are provided in Table 1. For a more detailed description of particular plots please refer to the project webpage: https://forestfire. biogeo.ru/index.php/en/.

\section{Sampling}

The sampling was performed between May 25 and June 20, 2015. Exact sampling dates were chosen for each ecoregion with the aim of their phenological synchronization. We referred to the beginning of bird cherry (Prunus padus L., 1753) flowering (World atlas..., 1964) to calculate the lag in sampling between the re- gions. At each plot we randomly collected four intact soil samples for springtails with a soil corer. To avoid possible edge effect during sampling we took soil monoliths not closer than $3 \mathrm{~m}$ from the plot edge. Each soil sample had the diameter of $5 \mathrm{~cm}$ and a depth of 6-8 cm (depending on the thickness of the organic horizon). In total we collected 96 samples. Collected samples were put into plastic bags and transferred to the laboratory in isothermic containers at a temperature below $+10^{\circ} \mathrm{C}$.

\section{Extraction and Identification}

In the laboratory soil samples were extracted using Tullgren funnels into the mixture of alcohol, water and ethylene glycol with a ratio of 80:15:5 respectively. Extraction lasted for 
four days. This time was sufficient for the substrate to reach air-dry condition. All springtails were slide-mounted in the cavity slides using a mixture of lactic acid and glycerol with a ratio of 3:1 respectively. Animals were then identified to the species level using applicable determination keys (Babenko et al., 1994; Fjellberg, 1998, 2007; Bretfeld, 1999; Potapov, 2001; Hopkin, 2007). After identification we assigned each species to one of the biogeographic distribution types (trans-holarctic, trans-palaearctic, western-palaearctic, eastern-palaearctic, cosmopolitan or unknown) following Babenko and Fjellberg (2006) and Babenko (2012).

\section{Statistical analysis}

Samples collected within the same forest plot were considered pseudoreplicates (Kozlov, 2014). Thus all values derived from them were averaged to represent a single data unit per plot. Differences between the means in burnt and control forests were tested with a two-way ANOVA with the categorical factors "Fire" and "Ecoregion" and their interaction. Data normality and heterogeneity were tested prior to the analysis. Because abundance of most species had non-normal distribution, we performed $\ln (x+1)$ transformation of data. In a case of testing the collembolans abundance belonging to different biogeographic distribution types, we left the data untransformed. If ANOVA returned significant results, we further tested the significance of differences between the means with the Tukey HSD test $(p<0.05)$. ANOVAs were done using Statistica 10.0 software package. For the analysis of the dominance structure of collembolan communities we recognized species with the relative abundance not less than $12.4 \%$ as dominant ones (Engelmann, 1978). Shannon diversity index (H') and Pielou evenness index (J') were calculated according to Shannon-Pielou index (Magurran, 1988). Similarity of springtail communities of the studied ecoregions was assessed with the cluster analysis (Bray-Curtis similarity index, complete linkage design). Before the analysis, the abundance of all species was square root transformed for normalization. Clustering was performed using Biodiversity Pro 2.0 software.

\section{Results}

Ecoregional differences in the species composition

In total we collected and identified 6799 springtail individuals representing 14 families, 41 genera and 94 species. Data on the average species abundance and their biogeographic distribution type are provided in Appendix 1.

Total springtail abundance significantly increased from north (18608 ind. $\mathrm{m}^{-2}$ ) to south (57152 ind. $\mathrm{m}^{-2}$ ) (ANOVA, $\mathrm{F}=15.8, \mathrm{P}<0.0001$ ), but was not affected by "Fire" treatment. Average species richness in the same manner increased from north (12 species) to south (21 species) (ANOVA, $\mathrm{F}=9.1, \mathrm{P}<0.002$ ), with no effect of "Fire". The highest total number of species was observed in Smolensk-Priuralskiy ecoregion (68 species); it was a bit lower in Pribaltiiskiy-Vetluzhskiy ecoregion ( 55 species) and the lowest in Kola-Karelian ecoregion (35) species. No significant difference in springtail diversity measured by Shannon diversity index was found between treatments. Highest Shannon diversity was observed in burnt plots of Smolensk-Priuralskiy and in control plots of Pribaltiiskiy-Vetluzhskiy ecoregions and lowest in burnt plots of Kola-Karelian ecoregion. Pielou evenness index was higher in burnt plots of Kola-Karelian ecoregion and lowest in control plots of Smolensk-Priuralskiy ecoregion (Appendix 1).

The most frequent species found in all studied ecoregions were Isotoma viridis, Lepidocyrtus lignorum, L. lanuginosus, Entomobrya nivalis, Folsomia quadrioculata, Parisotoma notabilis, Pygmarrhopalites cf secundarius, Isotomiella minor, Micraphorura absoloni, Willemia anophthalma, W. denisi, Mesaphorurayosii, M. tenuisensillata, and Micranurida pygmaea. Among them I. minor, M. yosii, P. notabilis, F. quadrioculata and $W$. anophthalma dominated (Bold in Appendix 1).

The average abundance of $I$. minor and $W$. 
anophthalma was significantly lower in the burnt plots than in the controls (ANOVA, $\mathrm{F}=4.46$, $\mathrm{P}<0.049$ and $\mathrm{F}=6.73, \mathrm{P}<0.018$, respectively). In addition, total abundance of $I$. minor was significantly higher in middle and southern ecoregions, than in northern taiga ecoregion (ANO$\mathrm{VA}, \mathrm{F}=5.96, \mathrm{P}<0.01$ ), while the abundance of $W$. anophthalma fluctuated between the ecoregions. It was the highest in PribaltiiskiyVetluzhskiy ecoregion (ANOVA, F=12.02, $\mathrm{P}<0.0005$ ). The average abundance of $F$. quadrioculata, $P$. notabilis and $M$. absoloni significantly increased from northern to southern ecoregion (ANOVA, $\mathrm{F}=6.21, \mathrm{P}<0.009 ; \mathrm{F}=49.9$, $\mathrm{P}<0.000001$ and $\mathrm{F}=25.06, \mathrm{P}<0.00001$ respectively). Other species did not show significant differences between the treatments.

The dominance structure of springtail communities was also affected by fire. Control plots were always dominated by I. minor. Dominant species in the burnt plots varied across ecoregions. M. yosii was the most abundant species in Kola-Karelian, I. minor in Pribaltiiskiy-Vetluzhskiy and Mesaphorura hylophila in SmolenskPriuralskiy ecoregion respectively.

In Kola-Karelian ecoregion I. minor was clearly more numerous in the control plots (ANOVA, $\mathrm{F}=9.128, \mathrm{P}<0.02$ ), than in the burnt ones. The decrease of the abundance of $W$. anophthalma in the burnt plots was only marginally significant (ANOVA, $\mathrm{F}=4.74, \mathrm{P}<0.072$ ). Several species like Mesaphorura krausbaueri, Protaphorura subarctica and P. pseudovanderdrifti were recorded only in the burnt plots (Appendix 1).

In Pribaltiiskiy-Vetluzhskiy ecoregion, none of the springtail species were significantly affected by "Fire" treatment. Although many species with low abundance were found only in burnt plots: Chouretinula inermis, Xenylla tullbergi, Friesea truncata, Cryptopygus cf. bipunctatus, Desoria hiemalis, Folsomia dovrensis, Proisotoma minima, Vertagopus haagvari, Entomobrya nicoleti, Orchesella cincta and Sminthurinus concolor.

In Smolensk-Priuralskiy ecoregion the abundance of Pygmarrhopalites principalis was significantly higher in control than in the burnt plots (ANOVA, $\mathrm{F}=6.57, \mathrm{P}<0.04$ ). Also, some species such as Mesaphorura critica, M. hylophila, M. macrochaeta, P. pseudovanderdrifti, C. inermis, Xenylla cf. maritima, Desoria nivea, Folsomia fimetarioides, Pachyotoma crassicauda, E. nicoleti, Lepidocyrtus pallidus, Sminthurides malmgreni, S. cf. signatus, S. schoetti, Pygmarrhopalites cf. secundarius and Sminthurus viridis were found only in burnt plots. (Appendix 1).

At the species level we found only few significant differences in the abundance between burnt and control forests. In addition, some springtail individuals (e.g. most of juveniles) were identified only to a family level. To include them into the analysis we also studied the effect of burning on the abundance of collembolan families. The abundance of collembolans from Arrhopalitidae family was significantly lower in burnt plots (ANOVA, $\mathrm{F}=6.25$, $\mathrm{P}<0.02$ ) with no effect of "Ecoregion" on it. The abundance of Onychiuridae springtails was significantly affected by "Ecoregion" and by its interaction with "Fire". It was much higher in the burnt plots of Smolensk-Priuralskiy ecoregion, but lower in the burnt plots of Pribaltiiskiy-Vetluzhskiy ecoregion compared to the respective controls (ANOVA, $\mathrm{F}=4.53, \mathrm{P}<0.02$ ). The abundance of springtails belonging to Isotomidae and Neelidae families significantly increased from north to south (ANOVA, $F=4.66$, $\mathrm{P}<0.02$ and $\mathrm{F}=4.44, \mathrm{P}<0.03$ respectively), however, their abundance was not significantly affected by burning. Other families were significantly affected by none of the factors nor their interaction.

\section{Faunistic similarity}

The cluster analysis revealed considerable modulation effect of "Ecoregion" on the fireinduced changes in the faunistic composition of collembolan assemblages. Burnt and unburnt plots from Kola-Karelian ecoregion were clearly dissimilar to the others and formed a separate cluster (Fig.2). The communities from burnt and unburnt forests of Pribaltiiskiy-Vetluzhskiy ecoregion served as the core of the second cluster and were the most similar between each 


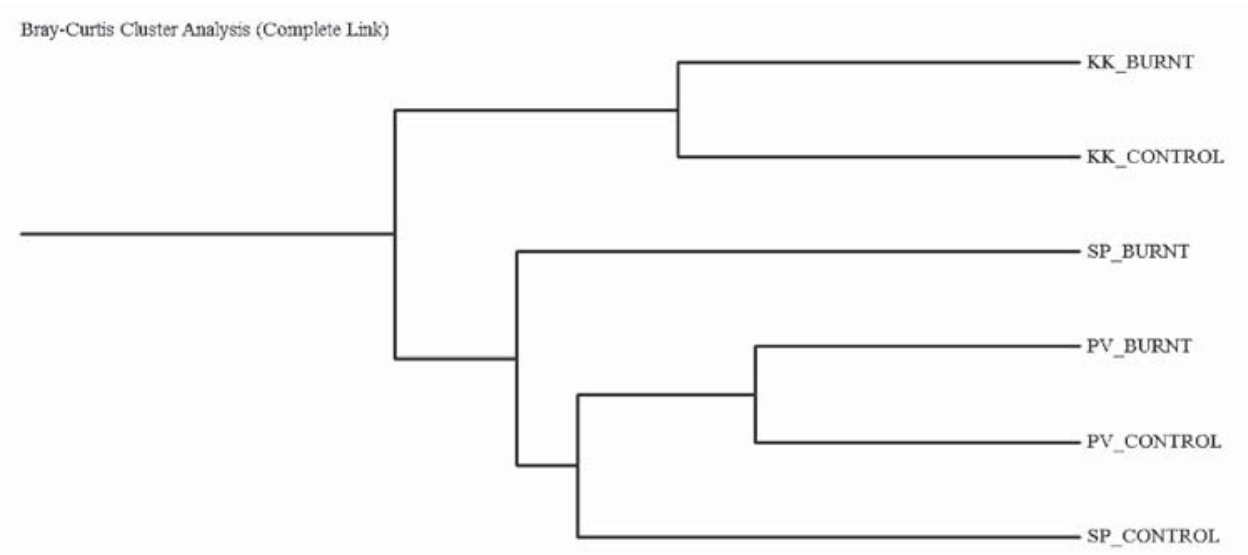

0. \% Similarity $\quad 50, \quad 100$

Fig. 2. Cluster analysis of springtail communities in the burnt and unburnt forests of the three studied ecoregions (Bray-Curtis index of similarity, Complete linkage). Data is square root transformed. Ecoregions are abbreviated as follows: KK — Kola-Karelian, PV — Pribaltiiskiy-Vetluzhskiy, SP — SmolenskPriuralskiy.

Рис. 2. Дендрограмма кластерного анализа сообществ коллембол в сгоревших и контрольных лесах, трёх исследуемых экорегионов (индекс сходства Брея-Кёртиса, метод полной связи). Данные трансформированы извлечением квадратного корня. Сокращения: КK - Кольско-Карельский экорегион, PV - Прибалтийско-Ветлужский экорегион, SP - Смоленск-Приуральский экорегион.

other among all plots included into the analysis (Bray-Curtis similarity level of 70\%) (Fig. 2). Similarity between the communities in the Smolensk-Priuralskiy burnt and unburnt plots was the lowest and these communities were more similar to those from the Pribaltiiskiy-Vetluzhskiy ecoregion (Bray-Curtis similarity level $47 \%$ between each other) (Fig. 2).

\section{Biogeographic distribution types}

The abundance and species richness of springtail species sharing certain biogeographic distribution types was significantly different between the studied ecoregions (Fig.3 and Fig.4). Total abundance of west-palaearctic species was significantly affected by interaction of "Ecoregion" and "Fire" treatments. It was considerably higher in the burnt plots than in the controls in Smolensk-Priuralskiy ecoregion and in the Kola-Karelian ecoregion abundance of west-palaearctic springtail was higher in the controls (ANOVA, F=4.7, p<0.02) (Fig.3). "Ecoregion" had a strong effect on the total abundance of cosmopolitan, trans-palaearctic and trans-holarctic species. Their abundance significantly increased from northern to southern ecoregion (ANOVA, $\mathrm{F}=24.4, \mathrm{p}<0.00001$; $\mathrm{F}=4.49, \mathrm{p}<0.03$ and $\mathrm{F}=12.33, \mathrm{p}<0.0004$, respectively) (Fig. 3). Also, abundance of transholarctic species was higher in the control plots than in the burnt forests (ANOVA $\mathrm{F}=6.52$, $\mathrm{p}<0.02$ ).

Average species richness of cosmopolitan species significantly increased from north to south (ANOVA, F=18.3, p<0.00005) (Fig. 4). Species richness of west-palaeartic species was affected by interaction of factors "Ecoregion" and "Fire". It was higher in controls than in burnt plots of Kola-Karelian ecoregion, while in Smolensk-Priuralskiy ecoregion was reverse situation (ANOVA, $\mathrm{F}=4.28, \mathrm{p}<0.03$ ). Average species richness of trans-palaearctic and trans- 


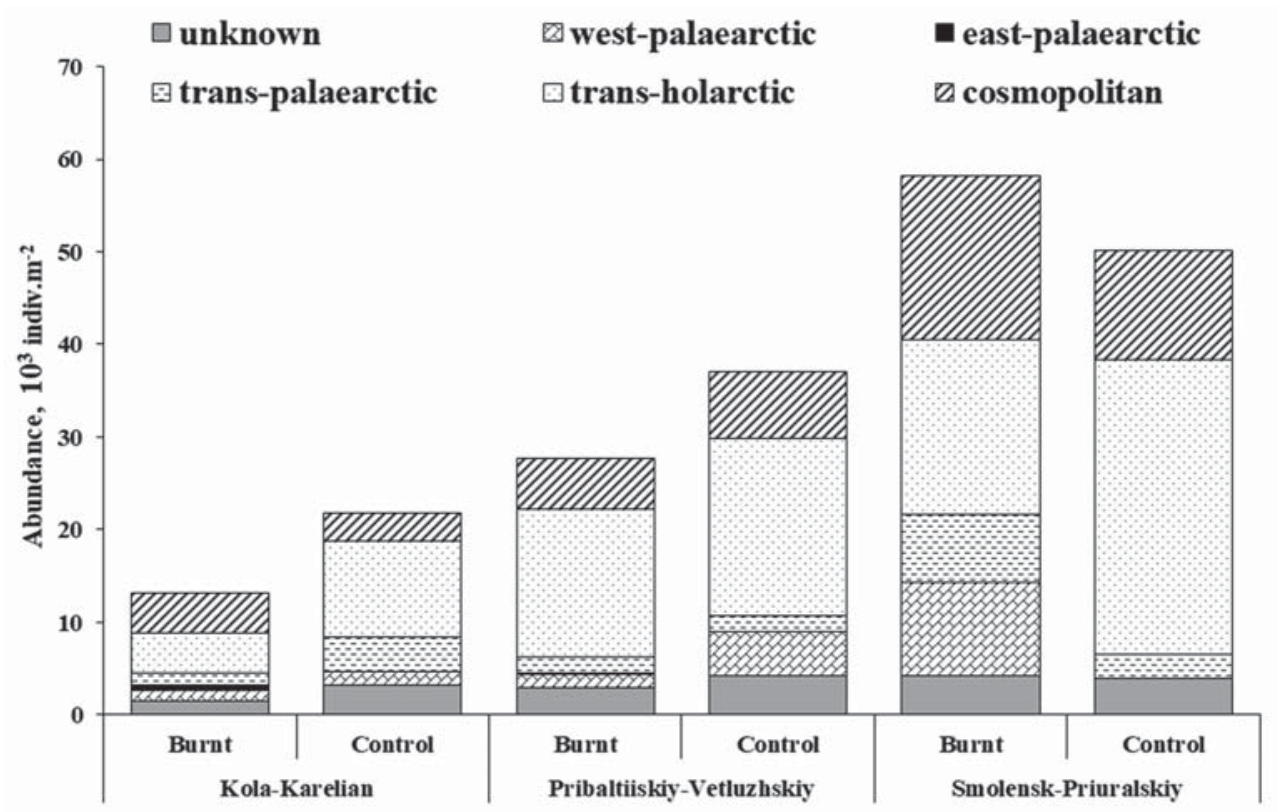

Fig. 3. Abundance of springtails $\left(10^{3}\right.$ ind. $\left.\mathrm{m}^{-2}, \mathrm{n}=4\right)$ sharing different biogeographic distribution types in the burnt and control forests of the three studied ecoregions.

Рис. 3. Численность ногохвосток $\left(10^{3}\right.$ экз. $\left.\mathrm{M}^{-2}, \mathrm{n}=4\right)$ с разными типами биогеографического распространения в сгоревших и контрольных лесах, трёх исследуемых экорегионов.

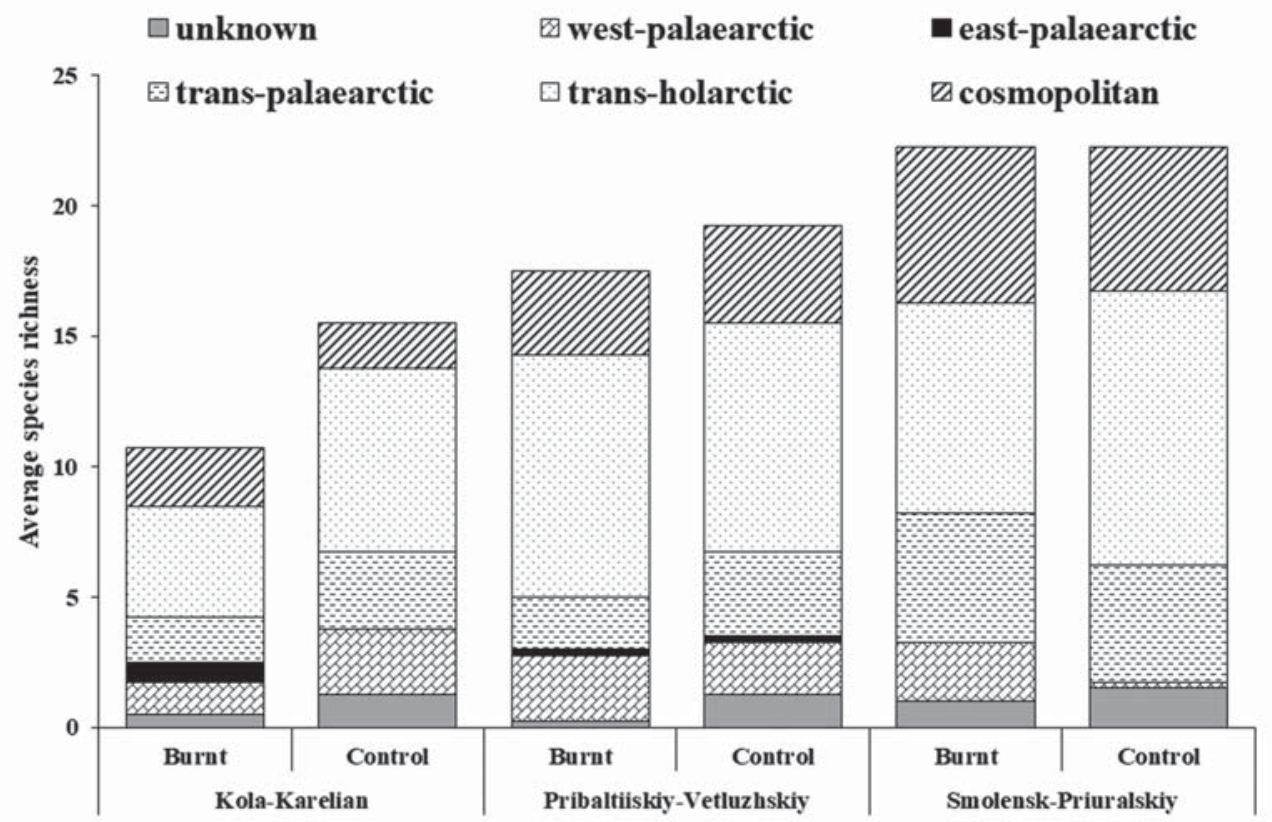

Fig. 4. Average species richness of springtails $(n=4)$ sharing different biogeographic distribution types in the burnt and control forests of the three studied ecoregions.

Рис. 4. Среднее число видов ногохвосток $(\mathrm{n}=4)$ с разными типами биогеографического распространения в сгоревших и контрольных лесах, трёх исследуемых экорегионов. 
holarctic species was lower in northern taiga ecoregion that in southern and middle ecoregions (ANOVA, $\mathrm{F}=3.8, \mathrm{p}<0.04$ and $\mathrm{F}=9.33$, $\mathrm{p}<0.002$, respectively). In addition, the number of trans-holarctic species in control plots was higher than in burnt forests, but this effect was only marginally significant (ANOVA, $\mathrm{F}=4.28$, $\mathrm{p}<0.053)$. Average species richness of species with unknown distribution was lower in burnt plots that in controls (ANOVA, $\mathrm{F}=5.9, \mathrm{p}<0.025$ ) (Fig. 4).

\section{Discussion}

In our study we revealed approximately one half of the total springtail species richness known by now for the European Russia's boreal forests (Kuznetsova, 1985; Chernova, Kuznetsova, 2000; Kuznetsova, 2002). According to Kuznetsova and Krest'yaninova (1998), indigenous springtail communities in this biome are mainly dominated by I. minor, which shows the clear preference to forested habitats. The absence of this species among dominants of soil microarthropod communities is assumed to indicate soil disturbance (Kuznetsova, Krest'yaninova, 1998). Our findings on the effects of fire on the springtail dominance structure further support this assumption for two ecoregions, as the abundance of I. minor considerably decreased in the burnt forests in Kola-Karelian and SmolenskPriuralskii ecoregions. Similar pattern was discovered for the abundance of $W$. anophthalma. Relatively high abundance and good representation of the mentioned species allows supposing them as good indicators of disturbances associated with recent forest fires. Indeed Malmström (2012) during her long-term study of the post fire recovery of springtail communities also found this species among ones who demonstrated reduced abundance for many years after a fire event. Nevertheless, in PribaltiiskiyVetluzhskiy ecoregion, total abundance of I.minor was slightly higher in burnt plots than in controls. We explain this by higher thermal insulation of the lower soil layer, which could provide better survival for soil living species like I. minor. Probably, this is ensured by thicker layer of ground litter made of needles, the level of which is higher in middle taiga in comparison with other subregions of boreal forest (Bazilevich, 1993; Borisov, Ganzhara, 2008).

It is remarkable that several species with relatively low abundance were found mainly in burnt plots (e.g. P. subarctica, P. armata, C. inermis, M. macrochaeta, F. quadrioculata, E. corticalis and others). Perhaps, that could be explained as after moderate disturbances proportion of non-dominant species is increased and this leads to diversification of springtail community structure (see Kuznetsova, Potapov, 1997). Moreover, proportion of species founded only in burnt plots is increasing from north to south, suggesting that in middle and southern taiga regions with more favorable climatic conditions, colonization rate of disturbed habitats by collembolans is relatively higher compared to northern taiga. This further points at the importance of considering ecoregional differences during the analysis of the effect of fire on springtails. The revealed ecoregional specificity is even more important if we analyze collembolan communities at the family level. The reduction of Arrhopalitidae abundance in the burnt plots and the respective increase of the number of Onychiuridae only in Smolensk-Priuralskiy ecoregion further highlights a very complex interaction between the effect of macroenvironmental factors and fire effects across extensive biomes like boreal forests (Hennig-Sever et al., 2001; Urbanovičova et al., 2013).

Unlike the abundance, forest fires have a quite moderate effect on the springtail community faunistic composition five years after burning. Fire-induced shifts in the faunistic composition are overruled by ecoregional differences. This points at the necessity of considering local environmental conditions when making spatially extensive projections of the fire effects on soil communities and soil biodiversity in particular (Zaitsev et al., 2016). Despite that, fires had the ecoregion-specific impact on the springtail abundance and richness of species sharing certain biogeographic distribution types. The increase 
of west-palaearctic species richness and abundance in the burnt forest plots of SmolenskPriuralskiy ecoregion suggests that this group is biogeographically more closely bound to the study biome. More consistent decrease of transholarctic species richness and abundance in burnt plots could be explained by wider distribution of this group, which probably leads to reduced resistance to regional-specific disturbances.

We conclude that five years after burning, springtail community faunistic composition in the Russian North-West taiga forest is only slightly affected by fire-induced disturbances and is rather determined by ecoregional differences. There is a certain group of springtail species, which benefit from the post-fire effects. Obviously, this positive response of some species to burning occurred due to lack of predation and higher ecological plasticity of these springtail species. However, even slight shifts in the species composition after fire result in the changes of the spectra of the species biogeographic distribution types in pyrogenic forests. It is very important to encounter for the type of disturbance when estimating the sensitivity of species to the environmental degradation processes.

\section{Acknowledgments}

The authors are grateful to the regional forest authorities of the Murmansk, Moscow, and Tver Regions, as well as the Republic of Karelia for providing us with the data on the location and history of burnt forests. We express our gratitude to Dr. Arne Fjellberg and Dr. Mikhail Potapov for valuable taxonomic advice during this work. We thank D. Korobushkin, S. Shakhab, T. Yazrikova, A. Gorbunova, and A. Zaytseva for the assistance during sampling and extraction of animals.

The study was supported by the Russian Science Foundation grant \# 14-14-00894.

\section{References}

Babenko A.B. 2012. Springtails (Hexapoda, Collembola) of tundra landscapes of the Kola Peninsula // Entomol. Rev. Vol.92. No.5. P.497-515.
Babenko A.B., Chernova N.M., Potapov M.B., Stebaeva S.K. 1994. [Collembola of Russia and adjacent countries: Family Hypogastruridae]. Moscow: Nauka. 335 p. [In Russian]

Babenko A.B., Fjellberg A. 2006. Collembola Septentrionale. A catalogue of springtails of the Arctic regions. Moscow: KMK Scientific Press. 190 p.

Bazilevich N.I. 1993. [Biological Productivity of Ecosystems in Northern Eurasia]. Moscow: Nauka. 293 p. [In Russian]

Borisov B.A., Ganzhara N.F. 2008. Geographical features of the distribution and renewal of easily decomposable organic matter in virgin and arable zonal soils of European Russia // Eurasian Soil Sci. Vol.41. No.9. P.946-952.

Bretfeld G. 1999. Synopses on Palearctic Collembola. Symphypleona // Abh. Ber. Naturkundemus. Görlitz. Vol. 71. No.1. P.1-318.

Chernova N.M., Kuznetsova N.A. 2000. Collembolan community organization and its temporal predictability // Pedobiologia. Vol.44. No.3. P.451-466.

Engelmann H.D. 1978. Zur Dominanzklassifizierung von Bodenarthropoden // Pedobiologia. Vol.18. P.378380 .

Fjellberg A. 1998. Collembola of Fennoscandia and Denmark: Poduromorpha. Part I. Leiden: Brill. 184 p.

Fjellberg A. 2007. Collembola of Fennoscandia and Denmark: Entomobryomorpha and Symphypleona. Part II. Leiden: Brill. 266 p.

Henig-Sever N., Poliakov D., Broza M. 2001. A novel method for estimation of wild fire intensity based on ash $\mathrm{pH}$ and soil microarthropod community // Pedobiologia. Vol.45. No.2. P.98-106.

Hopkin S.P. 1997. Biology of the springtails (Insecta: Collembola). Oxford: Oxford University Press. 340 p.

Hopkin S.P. 2007. A key to the Collembola (springtails) of Britain and Ireland. Shrewsbury: Field Studies Council. 245 p.

Huhta V., Persson T., Setälä H. 1998. Functional implications of soil fauna diversity in boreal forests // Appl. Soil Ecol. Vol.10. No.3. P.277-288.

IUSS Working Group WRB. 2015. World Reference Base for Soil Resources 2014, update 2015 International soil classification system for naming soils and creating legends for soil maps // World Soil Resources Reports No. 106. FAO. Rome. 193 p.

Juceviča E., Melecis V. 2002. Long-term dynamics of Collembola in a pine forest ecosystem: Proceedings of the Xth international Colloquium on Apterygota, Èeské Budijovice 2000: Apterygota at the Beginning of the Third Millennium // Pedobiologia. Vol.46. No.3. P.365-372.

Kozlov M.V. 2014. [Planning of ecological research: theory and practical recommendations]. Moscow: KMK Scientific Press. 171 p. [In Russian]

Kuznetsova N.A. 1985. [Fauna and population of springtails in coniferous forests of the European part of the USSR] [Candidate's Dissertation in Biology]. Moscow. 286 p. [In Russian] 
Kuznetsova N.A. 2002. Classification of collembolan communities in the east-european taiga // Pedobiologia. Vol.46. No.3. P.373-384.

Kuznetsova N.A., Krest'yaninova A.I. 1998. Dynamics of springtail communities (Collembola) in hydrological series of pine forests in southern taiga // Entomol. Rev. Vol.78. No.8. P.969-981.

Kuznetsova N.A., Potapov M.B. 1997. Changes in structure of communities of soil springtails (Hexapoda: Collembola) under industrial pollution of the southtaiga bilberry pine forests // Russian J. Ecol. Vol.28. No.6. P.386-392.

Magurran A.E. 1988. Ecological diversity and its measurement. Dordrecht: Springer Science+Business Media. 179 p.

Malmström A. 2012. Life-history traits predict recovery patterns in Collembola species after fire: A 10 year study // Appl. Soil Ecol. Vol.56. P.35-42.

Ogureeva G.N., Leonova N.B., Emelyanova L.G., Buldakova E.V., Kadetov N.G., Arkhipova M.V., Miklyaeva I.M., Bocharnikov M.V., Dudov S.V., Ignatova E.A., Ignatov M.S., Muchnik E.E., Urbanavicius G.P., Danilenko A.K., Rumyantsev V.Yu., Leontyeva O.A., Romanov A.A., Konstantinov P.I. 2015. [Map "Biomes of Russia" (scale 1: 7500 000) In: A series of nature maps for highschools]. Moscow: Finansovy and Organizatsionny Konsalting. 200 p. [In Russian]

Petersen H., Luxton M. 1982. A comparative analysis of soil fauna populations and their role in decomposition processes // Oikos. Vol.39. P.288-388.
Potapov M. 2001. Synopses on Palearctic Collembola. Vol.3. Isotomidae // Abhandl. Berich. Naturkund. Mus. Görlitz. Appendum. Vol.73. No.2. P.1-590.

Rusek J. 1998. Biodiversity of Collembola and their functional role in the ecosystem // Biodivers \& Conserv. Vol.7. No.9. P.1207-1219.

Seastedt T.R. 1984. The role of microarthropods in decomposition and mineralization processes // Ann. Rev. of Entomol. Vol.29. No.1. P.25-46.

Taskaeva A.A. 2009. Springtail (Collembola) assemblages in Floodlands of the taiga zone of the Republic of Komi // Entomol. Rev. Vol.89. P.956-974.

Taskaeva A.A. 2011. [Collembola of pine forests in a pollution gradient of timber industry complex emission] // Izv. Penz. gos. pedagog. univ. im.i V.G. Belinskogo. Vol.25. P.453-461 [in Russian].

Urbanovičová V., Miklisová D., Kováč L. 2013. The effect of windthrow, wild fire, and management practices on epigeic Collembola in windthrown forest stands of the High Tatra Mts (Slovakia) // Biologia (Bratislava). Vol.68. No.5. P.941-949.

World Atlas of Physical Geography. 1964. USSR Academy of Sciences. Moscow: Main Office of Geodesy and Cartography. 294 p. [In Russian]

Zaitsev A.S., Gongalsky K.B., Malmström A., Persson T., Bengtsson J. 2016. Why are forest fires generally neglected in soil fauna research? A mini-review // Appl. Soil Ecol. Vol.98. P.261-271.

Responsible editor K.G. Mikhailov 


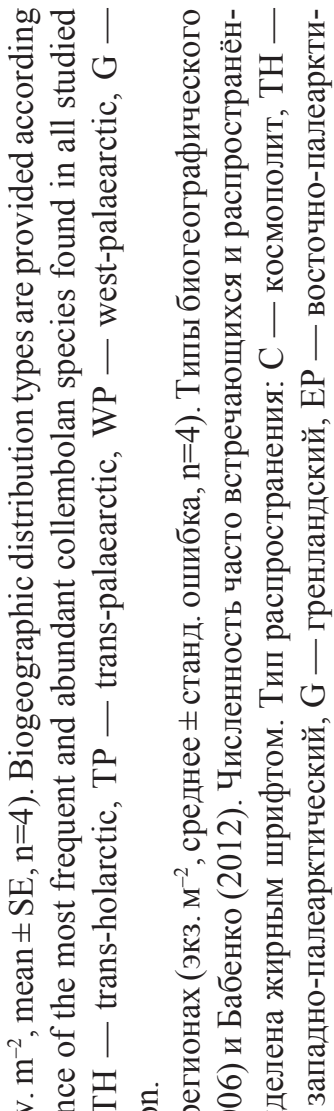
‥

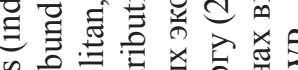

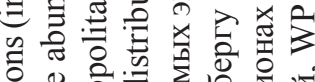

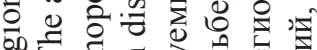

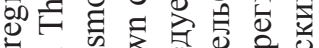

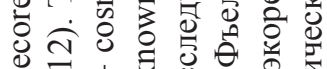

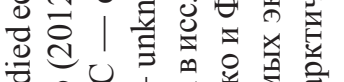

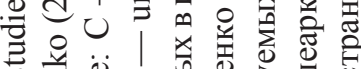

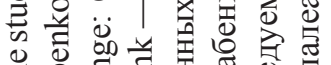

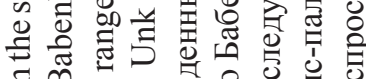

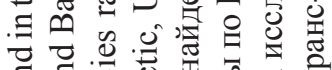

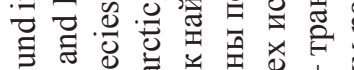

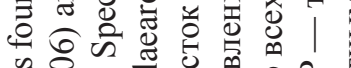

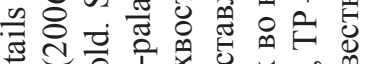

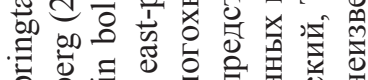

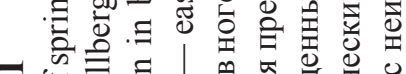

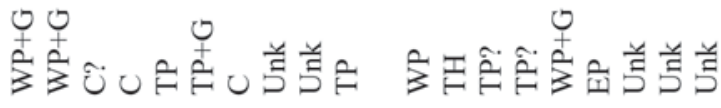

ঃ ิㅗㅇ

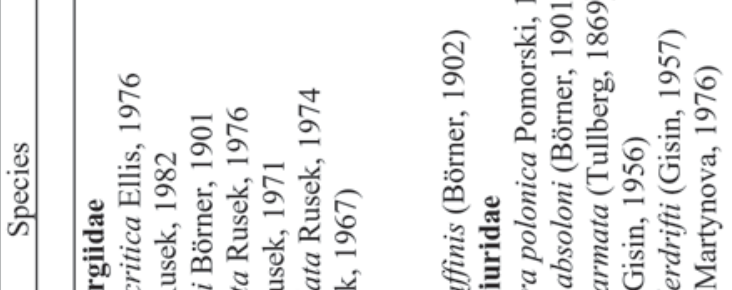

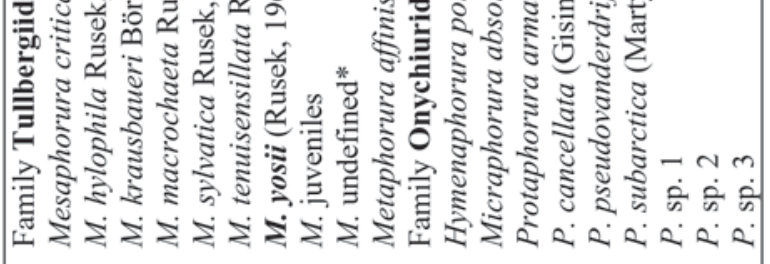




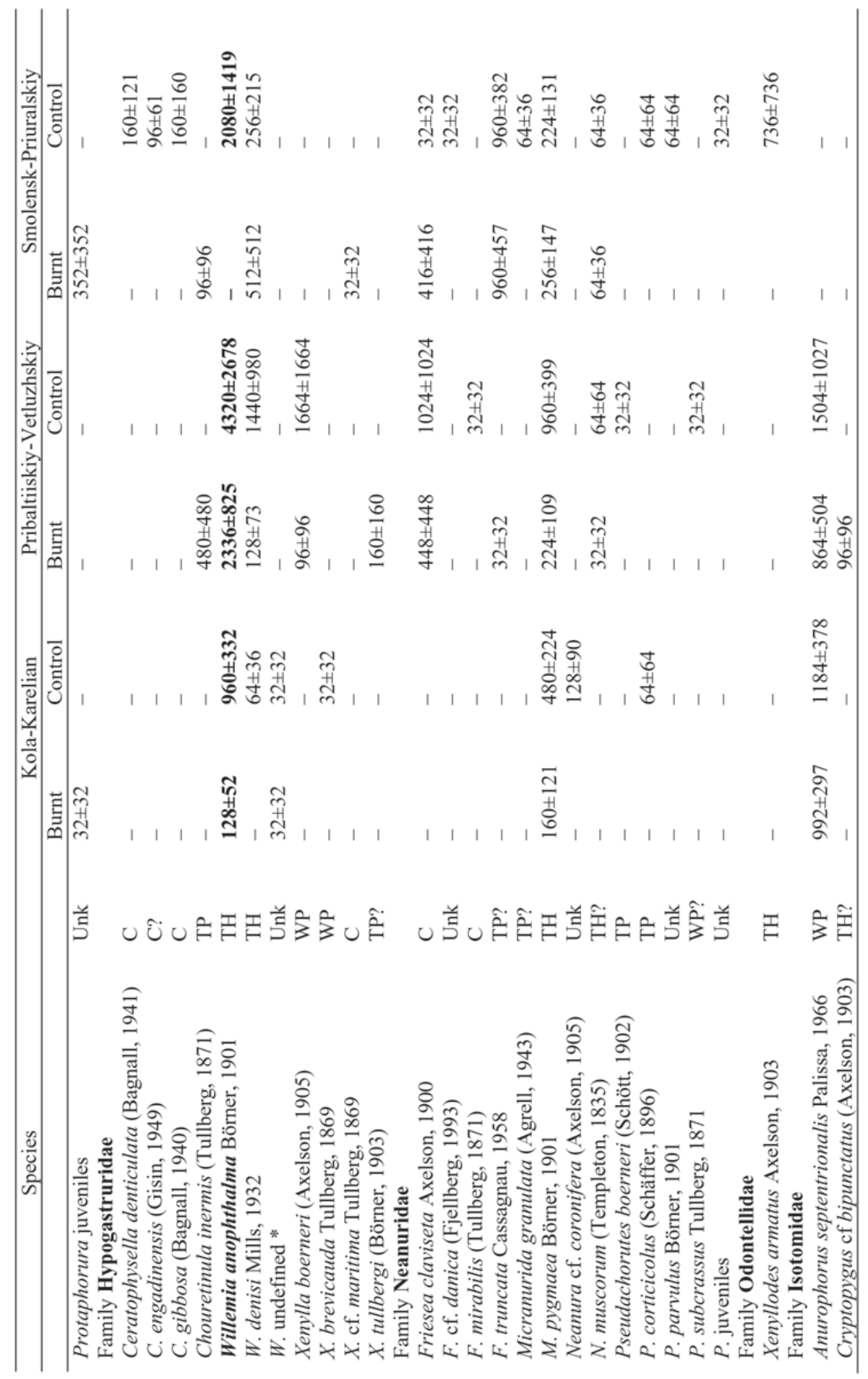




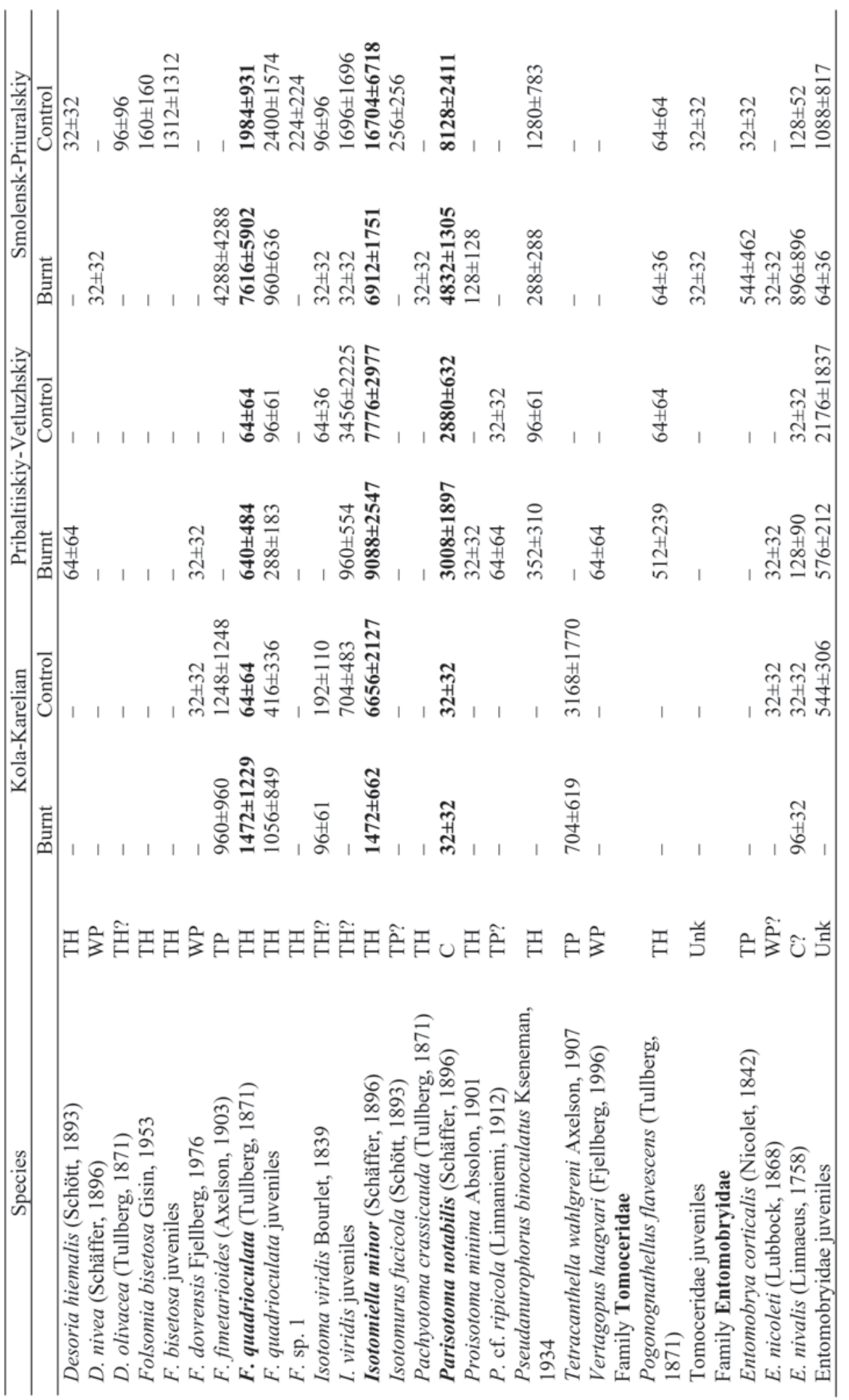




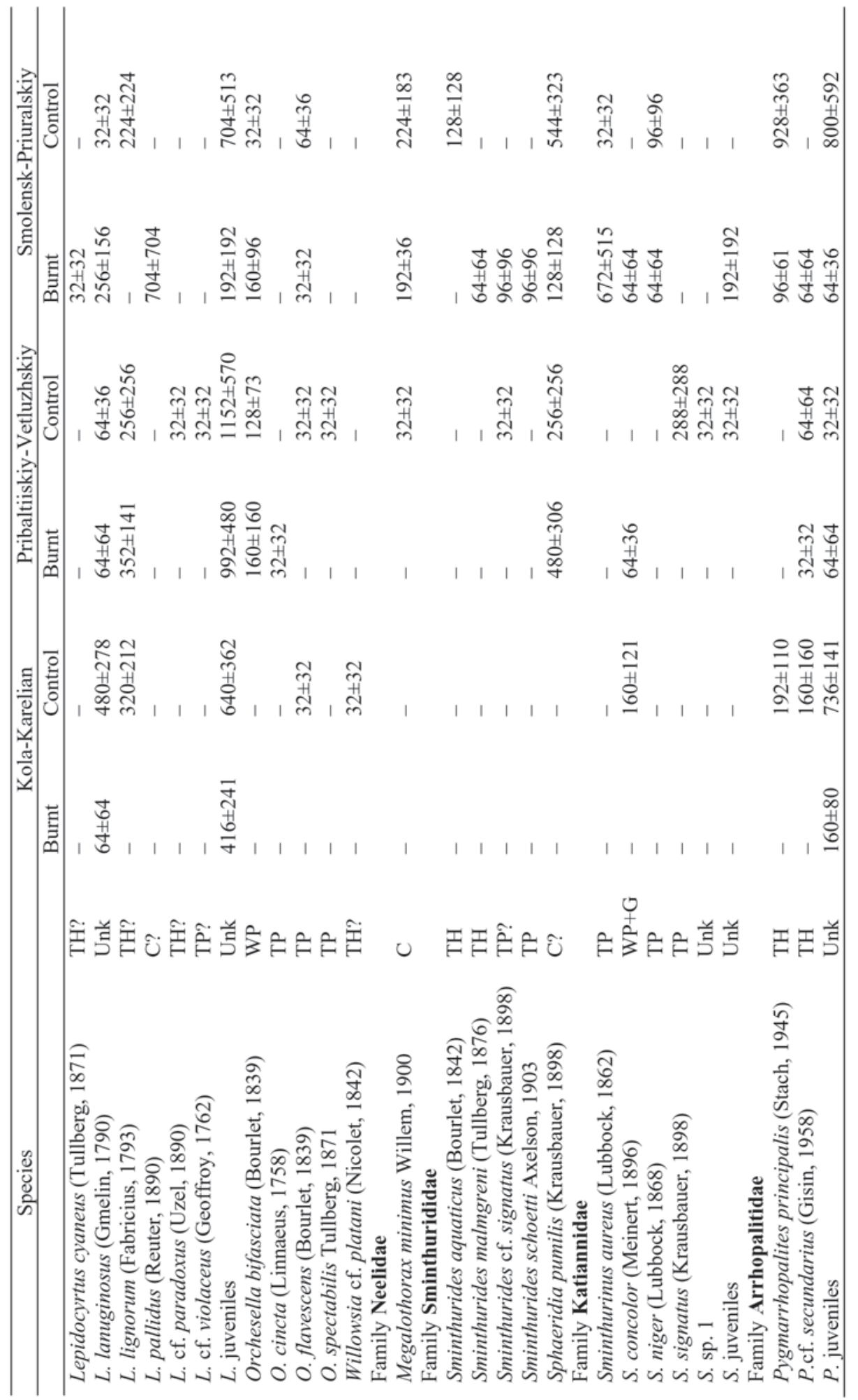




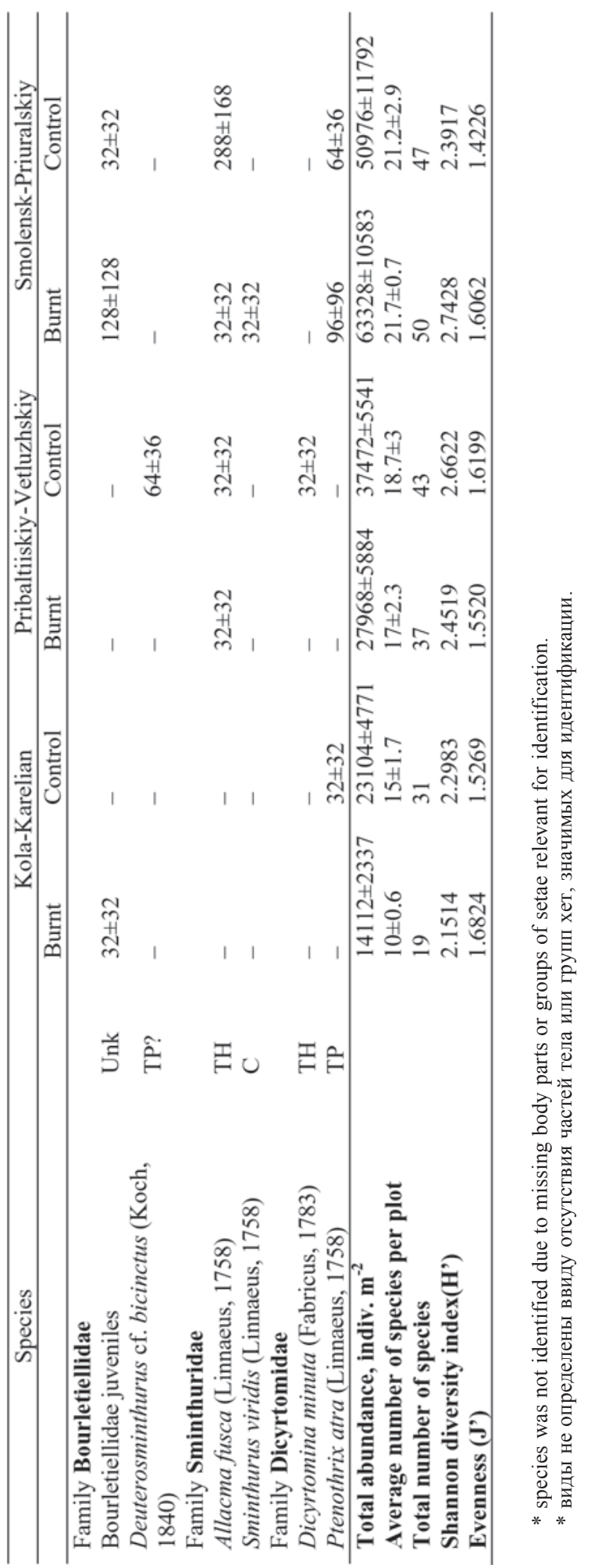

